\title{
Grand Challenges in Environmental Psychology
}

\author{
Patrik Sörqvist * \\ Department of Building, Energy and Environmental Engineering, University of Gävle, Gävle, Sweden
}

Keywords: environmental psychology, grand challenges, sociophysical environment, built environment, natural environment

Environmental psychology is the subdiscipline of psychological science that deals with psychological processes engaged in encounters between people and the built and natural environment (Stern, 2000). It covers all aspects of human behavior and mental life in relation to the sociophysical environment, whether considered as ambient environmental factors (e.g., noise, temperature, lighting), specific behavior settings (e.g., schools, offices, hospitals), the basic infrastructure of everyday life (e.g., energy and transportation systems), or in a broader sense, with regard to landscape and the relationship between built and natural aspects of human environments. Human behavior and mental life include, but are not limited to, perception and cognition, emotion, stress and mental fatigue, decision making, and social interactions, as manifest in covert and overt behavior. In short, environmental psychology is concerned with the facts of bi-directional influence in people-environment interactions; it considers how the sociophysical environment influences people and how people influence the environment (Gärling, 2014).

Global climate change is currently one of society's grand challenges (American Psychological Association, 2008; Hansen et al., 2013). Psychology cannot by itself slow or halt global warming, but it can explain why people sometimes engage in pro-environmental behavior that can mitigate climate change and it can help citizens overcome the psychological barriers of sustainable behavior (Gifford, 2011). A grand challenge for the environmental psychologist is to study, explain and predict how people's behavior can be changed to promote environmentally sustainable behavior (Vlek and Stag, 2007; Kaiser et al., 2013), environmentalism (Dietz et al., 1998) and conservation (Cialdini, 2003). One approach to this grand challenge involves the use of normative messages (Cialdini, 2003), framings (Hurlstone et al., 2014), social norms (Clark et al., 2008; Bertoldo et al., 2013) and educational programs (Ernst and Theimer, 2011) to reduce people's environmental footprint through communication and information interventions. This view aligns with a social psychological tradition with an emphasis on the study of how personality traits and attitudes shape behavior. Another approach-largely neglected in contemporary environmental psychology (Gärling, 2014) -focuses on how the environment itself should be built and modified to support and even require more sustainable human behavior (Johansson et al., 2016). This latter view stems from a behavioral and ecological approach to human functioning and focuses on how the environment shapes behavior (Scott, 2005). While the social psychological view has unquestionable merits, I envision a practicable way toward scientific breakthrough is to reintroduce this classic, ecological approach in environmental psychology and apply it to the modern problems of society.

The current anthropogenic global warming is coupled with an exponential human population growth that is placing tremendous demands on agricultural and natural resources (Foley et al., 2011). Environmental psychologists will play an important role in providing society with needed insights in several areas, including how to handle the social dilemmas of sharing resources in sustainable ways (Biel and Gärling, 1995; Anderies et al., 2013), how to implement techniques to mitigate the effects of increased energy demand (Nilsson et al., 2015) and how to understand the psychological consequences 
of scarcity (Griskevicius et al., 2013). One way to deal with the consequences of the population growth is to build megacities with high residential densities, as there are gains in energy and transportation efficiency to be made which can help to mitigate the negative effects of human activity on the environment (Kennedy et al., 2015). A major challenge with this development, however, is that such urbanization can lead to built environments that many people will find unlivable. A likely scenario is that the availability and access to natural environments are reduced, whereby people risk the loss of restorative opportunities supported by interaction with nature (Hartig et al., 2014), at the same time that stressful experiences of crowding (Lederbogen et al., 2011), noise (Basner et al., 2015) and air pollution become more common (Folberth et al., 2015). Furthermore, large cities must allow for a emergency services and other functions to work around the clock. People's dependency on artificial lighting will probably increase, and consequently so will also the usurpation of energy resources (Maleetipwan-Mattsson et al., 2016). The environmental psychologist faces the need to understand the effects of new environmental, work and living conditions for the human being, including land- (Hagerhall et al., 2004) and soundscapes (Nilsson and Berglund, 2006), schools (Clark et al., 2013), offices (Hongisto et al., 2016), and hospitals (Ulrich et al., 2008). The grand challenge is to act proactively, to study the general laws of how ambient factors and behavioral settings influence humans, and to develop models-well-grounded in theory and sound conceptualization-to predict the effects of alternative future environments.

To this end, environmental psychology will have to confront a range of theoretical, methodological and conceptual challenges. These include applying knowledge from cognitive psychologyon memory, attention, perception and performance (Sörqvist,

\section{REFERENCES}

American Psychological Association (2008). Society's Grand Challenges: Insights from Psychological Science. Downloaded on March 7th 2016. Available online at: http://www.apa.org/research/action/gc-climate-change.pdf

Anderies, J. M., Janssen, M. A., Lee, A., and Wasserman, H. (2013). Environmental variability and collective action: experimental insights from an irrigation game. Ecol. Econ. 93, 166-176. doi: 10.1016/j.ecolecon.2013.04.010

Basner, M., Brink, M., Bristow, A., de Kluizenaar, Y., Finegold, L., Hong, J., et al. (2015). ICBEN review of research on the biological effects of noise 2011-2014. Noise Health 17, 57-82. doi: 10.4103/1463-1741.153373

Bertoldo, R., Castro, P., and Bousfield, A. B. S. (2013). Pro-environmental beliefs and behaviors: two levels of response to environmental social norms. Rev. Latinoam. Psicol. 45, 435-446. doi: 10.14349/rlp.v45i3.1485

Biel, A., and Gärling, T. (1995). The role of uncertainty in resource dilemmas. J. Environ. Psychol. 15, 221-233. doi: 10.1016/0272-4944(95)90005-5

Cialdini, R. B. (2003). Crafting normative messages to protect the environment. Curr. Dir. Psychol. Sci. 12, 105-109. doi: 10.1111/1467-8721.01242

Clark, C., Head, J., and Stansfeld, S. A. (2013). Longitudinal effects of aircraft noise exposure on children's health and cognition: a six-year follow-up of the UK RANCH cohort. J. Environ. Psychol. 35, 1-9. doi: 10.1016/j.jenvp.2013. 03.002

Clark, J. K., Wegener, D. T., and Fabrigar, L. R. (2008). Attitudinal ambivalence and message-based persuasion: motivated processing of proattitudinal information and avoidance of counterattitudinal information. Pers. Soc. Psychol. Bull. 34, 565-577. doi: 10.1177/0146167207312527
2010, 2015) - to classic questions in environmental psychology, such as how natural environments can facilitate restoration from attentional fatigue (Kaplan, 1995); how brain imaging methods can be employed to address how the human brain interacts with the built and natural environment (Lederbogen et al., 2011; Lambert et al., 2015); and how evolutionary perspectives can inform environmental design (Joye, 2007). The challenges also include understanding the limits of these perspectives (Joye and van den Berg, 2011) and questioning commonly accepted claims; for example, asking whether the natural environment always has an advantage over the built environment with regard to its cognitive effects. I envision the specialty section on environmental psychology to be a place for researchers to express and discuss empirical findings, opinions, theories and hypotheses channeled through publication forms not available in any other environmental psychology outlet. The Frontiers' publication platform with article types like opinion, methods and hypothesis and theory provides an excellent opportunity for scientific debate about the fundamental mechanisms of psychological phenomena which I encourage authors to exploit for empirical, methodological, theoretical and conceptual development of our field.

\section{AUTHOR CONTRIBUTIONS}

The author confirms being the sole contributor of this work and approved it for publication.

\section{ACKNOWLEDGMENTS}

This paper was written with support from the Swedish Area Group of Environmental Psychology.

Dietz, T., Stern, P. C., and Guagnano, G. A. (1998). Social structural and social psychological bases of environmental concern. Environ. Behav. 30, 450-471. doi: 10.1177/001391659803000402

Ernst, J., and Theimer, S. (2011). Evaluating the effects of environmental education programming on connectedness to nature. Environ. Educ. Res. 17, 577-598. doi: 10.1080/13504622.2011.565119

Folberth, G. A., Butler, T. M., Collins, W. J., and Rumbold, S. T. (2015). Megacities and climate change-a brief overview. Environ. Pollut. 203, 235-242. doi: 10.1016/j.envpol.2014.09.004

Foley, J. A., Ramankutty, N., Brauman, K. A., Cassidy, E. S., Gerber, J. S., Johnston, M., et al. (2011). Solutions for a cultivated planet. Nature 478, 337-342. doi: 10.1038 /nature 10452

Gärling, T. (2014). Past and present environmental psychology. Eur. Psychol. 19, 127-131. doi: 10.1027/1016-9040/a000184

Gifford, R. (2011). The dragons of inaction: psychological barriers that limit climate change mitigation and adaptation. Am. Psychol. 66, 290-302. doi: 10.1037/a0023566

Griskevicius, V., Ackerman, J. M., Cantú, S. M., Delton, A. W., Robertson, T. E. Simpson, J. A., et al. (2013). When the economy falters, do people spend or save? responses to resource scarcity depend on childhood environments. Psychol. Sci. 24, 197-205. doi: 10.1177/0956797612451471

Hagerhall, C. M., Purcell, T., and Taylor, R. (2004). Fractal dimension of landscape silhouette outlines as a predictor of landscape preference. J. Environ. Psychol. 24, 247-255. doi: 10.1016/j.jenvp.2003.12.004

Hansen, J., Kharecha, P., Sato, M., Masson-Delmotte, V., Ackerman, F., Beerling, D. J., et al. (2013). Assessing "dangerous climate change": required reduction of 
carbon emissions to protect young people, future generations and nature. PLoS ONE 8:e81648. doi: 10.1371/journal.pone.0081648

Hartig, T., Mitchell, R., de Vries, S., and Frumkin, H. (2014). Nature and health. Annu. Rev. Public Health 35, 207-228. doi: 10.1146/annurev-publhealth032013-182443

Hongisto, V., Haapakangas, A., Varjo, J., Helenius, R., and Koskela, H. (2016). Refurbishment of an open-plan office-environmental and job satisfaction. J. Environ. Psychol. 45, 176-191. doi: 10.1016/j.jenvp.2015.12.004

Hurlstone, M. J., Lewandowsky, S., Newell, B. R., and Sewell, B. (2014). The effect of framing and normative messages in building support for climate policies. PLoS ONE 9:e114335. doi: 10.1371/journal.pone.0114335

Johansson, M., Sternudd, C., and Kärrholm, M. (2016). Perceived urban design qualities and affective experiences of walking. J. Urban Des. 21, 256-275. doi: $10.1080 / 13574809.2015 .1133225$

Joye, Y. (2007). Architectural lessons from environmental psychology: the case of biophilic architecture. Revi. Gen. Psychol. 11, 305-328. doi: 10.1037/10892680.11.4.305

Joye, Y., and van den Berg, A. (2011). Is love for green in our genes? a critical analysis of evolutionary assumptions in restorative environments research. Urban Forest. Urban Gren. 10, 261-268. doi: 10.1016/j.ufug.2011.07.004

Kaiser, F. G., Hartig, T., Duvier, C., and Brügger, A. (2013). Environmental protection and nature as distinct attitudinal objects: an application of the Campbell paradigm. Environ. Behav. 45, 369-398. doi: $10.1177 / 0013916511422444$

Kaplan, S. (1995). The restorative benefits of nature: toward an integrative framework. J. Environ. Psychol. 15, 169-182. doi: 10.1016/0272-4944(95) 90001-2

Kennedy, C. A., Stewart, I., Facchini, A., Cersosimo, I., Mele, R., Chen, B., et al. (2015). Energy and material flow of megacities. Proc. Natl. Soc. Am. 112, 5985-5990. doi: 10.1073/pnas. 1504315112

Lambert, K. G., Nelson, R. J., Jovanovic, T., and Cerd,á, M. (2015). Brains in the city: neurobiological effects of urbanization. Neurosci. Biobehav. Revi. 58, 107-122. doi: 10.1016/j.neubiorev.2015.04.007

Lederbogen, F., Kirsch, P., Haddad, L., Streit, F., Tost, H., Schuch, P., et al. (2011). City living and urban upbringing affect neural social stress processing in humans. Nature 474, 498-501. doi: 10.1038/nature10190
Maleetipwan-Mattsson, P., Laike, T., and Johansson, M. (2016). Factors affecting optimal lighting use in shared hospital environments: a case-study. Build. Environ. 96, 260-269. doi: 10.1016/j.buildenv.2015.11.026

Nilsson, A., Anderssson, K., and Jakobsson Bergstad, C. (2015). Energy behaviors at the office: an intervention study on the use of equipment. Appl. Energy 146, 434-441. doi: 10.1016/j.apenergy.2015.02.045

Nilsson, M. E., and Berglund, B. (2006). Soundscape quality in suburban green areas and city parks. Acta Acust. Acust. 92, 903-911.

Scott, M. M. (2005). A powerful theory and a paradox: ecological psychologist after barker. Environ. Behav. 37, 295-329. doi: 10.1177/0013916504270696

Sörqvist, P. (2010). Effects of aircraft noise and speech on prose memory: what role for working memory capacity? J. Environ. Psychol. 30, 112-118. doi: 10.1016/j.jenvp.2009.11.004

Sörqvist, P. (2015). On interpretation of the effects of noise on cognitive performance: the fallacy of confusing the definition of an effect with the explanation of that effect. Front. Psycho. 6:754. doi: 10.3389/fpsyg.2015.00754

Stern, P. (2000). Psychology and the science of human-environment interactions. Am. Psychol. 55, 523-530. doi: 10.1037/0003-066X.55.5.523

Ulrich, R. S., Zimring, C., Zhu, X., DuBose, J., Seo, H.-B., Choi, Y. S., et al. (2008). A review of the research literature on evidence-based healthcare design. Health Environ. Res. Des. J. 1, 61-125. doi: 10.1177/193758670800 100306

Vlek, C., and Steg, L., (2007). Human behavior and environmental sustainability: Problems, driving forces, and research topics. J. Soc. Issues 63, 1-19. doi: 10.1111/j.1540-4560.2007.00493.x

Conflict of Interest Statement: The author declares that the research was conducted in the absence of any commercial or financial relationships that could be construed as a potential conflict of interest.

Copyright (c) 2016 Sörqvist. This is an open-access article distributed under the terms of the Creative Commons Attribution License (CC BY). The use, distribution or reproduction in other forums is permitted, provided the original author(s) or licensor are credited and that the original publication in this journal is cited, in accordance with accepted academic practice. No use, distribution or reproduction is permitted which does not comply with these terms. 